\title{
Impact of forest policies and the economy of the soliga tribal's in biligiri rangaswamy temple wildlife sanctuary, South India
}

\begin{abstract}
The indigenous tribal peoples have been living in the forests for millions of years and their livelihood depends on the forest resources, they have symbiotic relationship with nature, before independence there is no much restriction to tribal's in the forest and they can live freely and use the forest resources. Government brought out different forest policies and declares the most of the forest areas into Wildlife Sanctuaries, National Parks, Tiger Reserves, Community Reserves and reserve forest to protect and conserve forest, it helps the wildlife and forest conservation and in another hand it has impacted the livelihood of the millions of tribal's. The major livelihood occupation of Soliga tribal's are Non-Timber Forest Products collection and sale and they also engaged in agriculture, labour and livestock rearing, they are earn income from different sources that 43 percent from labour, 45 percent from agriculture, 7 percent from sale of forest resources and 5 percent from sale of livestock. BRT reserve forest declares into wildlife sanctuary in 1974 and stopped the shifting cultivation and displaced settlements to periphery and allow the some of the settlement to stay inside the forest, NTFPs collection was banned in 2006 and Government did not provide any alternative employment and due to this 32.5 percent of them migrated outside for employment, it made adverse affect on Soliga tribal economy. The recent policy of Forest rights Act 2006 given some space for tribal's to get rights to collect NTFPs and use the forest land, even that also they are facing the relocation problem because of declare into Tiger Reserve in 2011. The study will focus on impact of forest policies and economic scenario of the Soliga tribes.
\end{abstract}

Keywords: soliga, tribals, wildlife sanctuary, forest, income
Volume I Issue 4 - 2017

\author{
Madegowda C,' C Usha Rao² \\ 'Ashoka Trust for Research in Ecology and the Environment, \\ India \\ ${ }^{2}$ Department of Studies in Social Work, University of Mysore, \\ India
}

Correspondence: Madegowda C,Ashoka Trust for Research in Ecology and the Environment, India, Email cmade@atree.org

Received: April 17,2017| Published: July 06, 2017

\section{Introduction}

The tribal economy is a forest-based economy. Tribals traditionally live within self-sufficient subsistence economy that depends on natural resources. Tribal's have relatively little exposure to the economy outside their region, many forest products are used one way or the other in the rites and ritual of the tribal's. ${ }^{1}$ Tribal people are traditional forest dwellers and they consider the forests as their nourishing mother who supplies them with food, fuel and fodder. ${ }^{2}$ Almost 90 percent of the tribal's still live in the forest tracts. As forest dwellers, their life support system has been intricately linked with the forest in the forms of 'anna', 'aarogya' and 'aasra' (food, well-being and security), the basis of their symbiotic relationship and their physical and cultural survival. ${ }^{3}$ The income difference between different tribes may arise due to the types of occupation opportunities they have in their areas. ${ }^{4}$ The tribal economy was based on subsistence agriculture and/ or hunting and gathering. ${ }^{5}$

Indian Forest Act that was first enacted by the colonial British government in 1865 and later on Government of India brought out different forest policies to protect forest and wildlife, due to the Wildlife Protection Act, 1972 and other forest policies, tribal's were displaced as their native places were declared wildlife sanctuary, national parks and tiger reserves and with government taken up mining and development projects. In the name of national development, tribal people are forced to relocate and give up their lands for dams and roads, industrial complexes and mines. The tribal has developed a symbiotic relationship with the forests. But realizing its commercial importance restrictions are imposed from time to time by the Government. These restrictions create conflict between the tribal's and the imposers as the tribal's think that the policies implemented would affect their socioeconomic and cultural life. ${ }^{1}$ Displacement of indigenous peoples not only leads to landlessness, but also to downward occupational mobility, poverty, child labour and loss of culture.

The Soliga tribal people have been living in the Biligiri Rangaswamy Temple (hereafter BRT) Wildlife sanctuary for centuries. The Soligas were a foraging and hunting community and their major livelihood depended on resources. The traditional economy of the Soliga is mostly based on shifting cultivation and collection of minor forest produce. ${ }^{6-7}$ Soligas earn 60 percent of their income from NTFP collection, agricultural labour and temporary work assignments with the forest department contribute about 30 percent to their earning ${ }^{9}$ the Soligas get 58. 6 percent from NTFPs collection, agricultural activities 22.7 percent and labour 8.6 per cent, allied 7.2 percent and others 2.8 percent of income per year per family ${ }^{10}$ it shows that they are getting different sources of income. The BRT reserve forest declares as Wildlife Sanctuary in 1974 under the Wildlife Protection Act, 1972. The forest department banned shifting cultivation and displaced the Soligas to the periphery and only a few of the Podus were allowed to stay inside the forest. In 2004, pursuant to the Supreme Court order, the State government prohibited the collection of NTFP for sale. The ban order was put into effect in BRTWS in 2006 and again the Government notified the BRT wildlife Sanctuary as a BRT tiger reserve in January 2011, it help the biodiversity conservation and in another hand it affect the livelihood of the Soliga tribal's. 


\section{Study area}

The BRT Wildlife Sanctuary is located in the Chamarajanagar district of Karnataka state. The BRT Wildlife Sanctuary spread in three taluks of Yelandur, Chamarajanagar and Kollegal of Chamarajanagar district of Karnataka state, India. The Sanctuary derives its name "BILIGIRI" from the white rocky cliff, the top of which resembles a tabletop and has the temple of Lord "VISHNU" locally known as Rangaswamy. The hill range also gets its name by the white mist and silver clouds that cover these lofty hills for a greater part of the year. This unique bio-geographical entity which is situated in the middle of the bridge between the Western and Eastern Ghats in South India is located between $11^{\circ} 43^{\circ}$ and $12^{\circ} 09^{\circ}$ North Latitude and $77^{\circ} 01^{\circ}$ and $77^{\circ} 15^{\circ}$ East Longitudes. The BRT Wildlife Sanctuary area spreads over $574.82 \mathrm{sq} \mathrm{kms}$. The BRT has reach biodiversity, there are 61 Podus situated in the interior as well as exterior of the forest area and a total of 2905 indigenous Soliga tribal families depend on this forest for their life.

\section{Objective of the study}

A. To study the economic scenario of the Soliga tribes.

B. To study the impact of the forest policies on Soliga tribes.

C. To understand the livelihood opportunities of the Soliga tribes.

\section{Methodology}

The study focuses on the Soliga tribal community in the BRT Wildlife Sanctuary of Chamarajanagar district, Karnataka state, India, excluding the non- tribal families. There are 61 Soligas Podus in the BRT Wildlife Sanctuary. Hence, the universe of the study constitutes 61 Soliga Podus. To have a greater representation the 61 Podus, 36 Podus were chosen by adopting a disproportionate stratified random sampling design, of the 1527 families 25 percent families were selected for the study. Only the head of the family/responsible person of the family was considered for the purpose of the interview, it may be male or female. Finally 370 families were selected for the study, most of them are male. A semi structured interview schedule was used for the collection of data from the household heads. Simple average methods, percentage, frequency and statistical tables and graphs are used for the analysis of the data (Table 1).

\section{Results}

\section{Economy of the soliga tribal's}

Age and Occupation of the respondents: It was suggested to categorize the age and occupation of the respondents covered under

Table I Impact of forest policies on Soliga tribals the scope of the study to realize the nature of job or task performed according to various seasons and the availability of job opportunities for them in various fields. An occupation providing significant amount of earning is considered as primary occupation and a task performed during free time or in the off season is considered as secondary occupation. Majority of the respondents as also individual family respondents had been engaged in agriculture occupation and earned an income from such agricultural activities. When individual respondents are engaged in their daily work as a laborer or works in the farmers' lands, collects Non Timber Forest Products (hereafter NTFPs) from the forest or is engaged in any other type of labour work, it is called as wage labour. In a Government job individual persons may be engaged or occupied in different Government departments which may be of a permanent or temporary nature. Private work means individual family members are engaged in private sector jobs for their livelihood. Therefore, for the present study occupations are classified into two categories- primary occupation and secondary occupation. The study also reveals that majority of the respondents are engaged in agriculture work which is a primary occupation and next to it are the wage laborers and the collection of NTFPs which are secondary occupations.

Table 2 indicates the age and occupation distribution among 370 respondents. The major source of occupation is agriculture, followed by wage labour, Government job and private work. Around 60 percent of the respondents belong to the age groups of 31-35 years and 46-50 years, 38 percent of the respondents are in the age groups of 51-55 years and 66-70 years and 26-30 years and the lowest 2 percent of the respondents fall in the age group of 20-25 years. All the respondents in the various age groups were occupied or engaged in agriculture. Respondents belonging to the age groups of 26-30 years and 3640 years were engaged in wage labour because they did not have agricultural land and very few respondents had Government and other work as a primary occupation.

Table 2 explains the distribution of the primary sources of occupation which for 74 percent of families is agriculture, 23 percent of families are wage labour and for the remaining three percent of the families is Government job and other work. Secondary occupation is followed by 58.6 percent of the families through wage labour. Around 36.4 percent of the respondents were not engaged in any secondary occupation because they continued as wage labour in both primary and secondary occupations, while some of the respondents were engaged in agriculture, Government job and other work and so had not engaged in any secondary occupation. The table shows that agriculture and wage labour are the main occupations, as the respondents do not have other sources of occupation, hence there is a need for different occupations to be made available for their livelihood.

\begin{tabular}{llll}
\hline Forest act & Importance & Impact in India & In general to brt \\
\hline $\begin{array}{l}\text { During the } \\
\text { British colonial }\end{array}$ & $\begin{array}{l}\text { To harvest } \\
\text { Forest timbers }\end{array}$ & & \\
era, the Forest & for commercial & Established that forest use by villagers was not a & \\
department was & purpose and & right. The indigenous tribal people who had lived & The Soliga tribals lived in the forest freely without \\
established in & restriction & freely lived in the forest but the Indian forest acts & restriction and they enjoyed the forest. \\
India I864 and & on use of & put restriction on use forest and Adivasis started & forest by local \\
Indian Forest & movement to get their rights in the forest. & \\
$\begin{array}{l}\text { Act I865, } \\
\text { Forest Act I878 }\end{array}$ & $\begin{array}{l}\text { communities } \\
\text { and tribals. }\end{array}$ & & \\
\hline
\end{tabular}


Table Continued....

\begin{tabular}{llll}
\hline Forest act & Importance & Impact in India & In general to brt \\
\hline & & $\begin{array}{l}\text { The transit of forest-produce and the duty livable } \\
\text { on timber and other forest-produce. Under }\end{array}$ & During these periods Soliga tribals allowed use forests for \\
Indian Forest & $\begin{array}{l}\text { Consolidates } \\
\text { the law relating } \\
\text { to forests }\end{array}$ & $\begin{array}{l}\text { the this policy put the restriction to tribals and } \\
\text { tocal people to use forest and brought to under }\end{array}$ & their livelihood, there no restriction on use of the forest.
\end{tabular}

\begin{tabular}{|c|c|c|}
\hline $\begin{array}{l}\text { Wildlife } \\
\text { Protection Act } \\
\text { I } 972\end{array}$ & $\begin{array}{l}\text { To control } \\
\text { poaching, } \\
\text { smuggling and } \\
\text { illegal trade } \\
\text { in wildlife and } \\
\text { its derivatives. } \\
\text { Protection } \\
\text { of the listed } \\
\text { endangered } \\
\text { flora and fauna }\end{array}$ & $\begin{array}{l}\text { Under the Wildlife Protection act most of the } \\
\text { forest areas was nationalize and in the same } \\
\text { period Large dams, mining activities take up for } \\
\text { national development. In the name of biodiversity } \\
\text { conservation many forest areas declare as Tiger } \\
\text { reserve and national parks, wildlife sanctuaries } \\
\text {,due to this millions of tribals and local forest } \\
\text { dwellers had been displaced and restricted the } \\
\text { rights of tribals and local forest dwellers., it } \\
\text { affected the livelihood of the tribals and local } \\
\text { forest dwellers. }\end{array}$ \\
\hline
\end{tabular}

To protect the

Amendment

to Wildlife

Protection Act

in 2002, banning

the collection

of NTFP for

commercial use wildlife and

fauna and to

put restriction

on use of the

protected areas

by the tribals

and local forest

dwellers.
The Non Timber Forest Products (NTFPs) collection ban restriction on tribal people use of the NTFPs for their livelihoods, tribal faced economic crises and they strata to migrating outside for employment, it also affected their culture.

\section{BRT Wildlife}

Sanctuary was

declared into

BRT Tiger

Reserve in 201I

$\begin{array}{ll}\text { The Forest } & \text { to help } \\ \text { Conservation } & \text { conserve the } \\ \text { Act } 1980 & \text { countries } \\ & \text { forests, }\end{array}$

Joint Forest Management with local

National Forest with local community to Policy of 1988.
To increase the tiger population in protected areas and' also increase number of tiger reserve in country in another hand government want to displace the indigenous Soliga tribal people from their native place.

It strictly restricts and regulates the dereservation of forests or use of forest land for non-forest purposes Pre-requisites for the diversion of forest land for non-forest purposes, this act helped the some

Under this forest policy Partnerships in forest management involving both the state forest departments and local communities, Government formed Village forest committees (VFCs) and in the protected are formed the Eco-development committees (EDCs)
Under this act BRT reserve forest dealer into Wildlife Sanctuary in 1974 had consequences for lives of their ancestor land, shifting cultivation was banned and thousand of Soliga tribal people were evicted from the forest, it affected the livelihood and traditional practices of the Soliga tribals and violates the tribal rights.

The ban of NTFPs in BRT wildlife sanctuary affected I5,000 Soliga tribals use to get 50 to 60 percent of income from NTFPs, NTFPs is major sources of income to Soligas, the collected NTFPs sold through the Government set up by the Large Scale Adivasi Multipurpose Cooperative Societies (LAMPS), those income used for their daily food, clothing, health, education not for any commercial purpose. The Soligas were not provided with any alternative livelihood opportunities when they were cut off from their main economic source which led to an economic crisis among the tribes. The ban of NTFPs in BRT wildlife sanctuary affected I5,000 Soliga tribals use to get 50 to 60 percent of income from NTFPs, NTFPs is major sources of income to Soligas, the collected NTFPs sold through the Government set up by the Large Scale Adivasi Multipurpose Cooperative Societies (LAMPS), those income used for their daily food, clothing, health, education not for any commercial purpose. $32.5 \%$ of the Soligas migrated to different places of Kodagu, Tamil Nadu, and Kerala, as well as to nearby coffee estates and villages for employment. Soliga families migrate from 10 to 300 days in a year which has affected the children's education, culture, health etc. the migrating populations are getting lose their traditions and customs and are adopting the new practices of outside locality.

The 6 I Podus that have been living since time immemorial inside the core and on the periphery of the tiger reserve and whose major livelihood is earned through the forest, will be displaced and will lose their rights, livelihood, and culture in the name of the tiger conservation The forest department putting the presser to Soligas to displacement form the forest areas.

This act not much influenced in the BRT wildlife sanctuary because of wildlife protection act in place, so the forest department put the use basic facilities like drinking water, housing, electricity without using the Forest Conservation act 1980.

Under this policy forest department formed the Ecodevelopment Committee (EDCs) in all the tribal and nontribal settlements or villages to protect the forest and taken up afforestration activities and some village developmental activities, initial they got some funds for activities initial two years, forest department taken up some of the activities than stopped all types of activities. 
Types and size of landholding patterns: The Soligas have lived in the BRT Wildlife Sanctuary forest since ancient times. Their economy was dependent on forest products and agriculture. The Soligas used to practice shifting cultivation. At that time there was no restriction on landholding, and depending on their capacity they used to cultivate the land. In 1974 the BRT reserve forest was declared as the Biligiri Rangaswamy Temple Wildlife Sanctuary. The Forest Department banned shifting cultivation and rehabilitated the Soligas residing in those places and provided houses for a few families, and distributed forest land unequally without relevant records. In 1960 the Government of Karnataka distributed revenue land among a few of the Soliga families living inside and on the periphery of the BRT Wildlife Sanctuary. Currently the Soligas are cultivating the forest land, revenue and leased lands. Forest land is the land provided by the Forest Department without record in 2010 under the Scheduled Tribes and Other Forest Dwellers (Recognition of Forest Rights Act, 2006). The Soligas received the title deed or Patta for the forest land. Revenue land is the land provided by the Revenue Department with RTC and Patta. Leased land is the land that the Soligas have taken on lease from the outsiders. The landholding patterns among the individual Soliga families are forest land, revenue land, and lease land.

The size and types of landholding patterns, measured in acres, distributed among the Soligas is shown in Table 3. From 0-50 cents to 5-6 acres of land were acquired by a cross spectrum of the families and included the Revenue, Forest land and other types of land. This meant that individuals cultivated more than one type of land within the forest. The table specifies that of the 370 respondents, 61.6 percent of the respondents were holding forest land. 11.9 percent of the respondents were holding revenue land and 20 percent of the respondents were landless. This meant that most of the Soligas were holding forest land while 25 percent of the respondents were landless which included those who cultivated the leased land and the landless families.

Table 2 Age and Occupation of the respondents N= 370 (100\%)

\begin{tabular}{|c|c|c|c|c|c|c|c|c|c|}
\hline \multicolumn{2}{|c|}{ Primary occupation } & \multirow[b]{2}{*}{$\begin{array}{l}\text { Wage } \\
\text { labour (\%) }\end{array}$} & \multirow[b]{2}{*}{$\begin{array}{l}\text { Government } \\
\text { job (\%) }\end{array}$} & \multirow[b]{2}{*}{$\begin{array}{l}\text { Other } \\
\text { works (\%) }\end{array}$} & \multirow[b]{2}{*}{$\begin{array}{l}\text { Total } \\
\text { (\%) }\end{array}$} & \multicolumn{4}{|c|}{ Secondaroccupation } \\
\hline $\begin{array}{l}\text { Age in } \\
\text { years }\end{array}$ & $\begin{array}{l}\text { Agriculture } \\
\text { (\%) }\end{array}$ & & & & & $\begin{array}{l}\text { Agriculture } \\
\text { (\%) }\end{array}$ & $\begin{array}{l}\text { Wage } \\
\text { labour (\%) }\end{array}$ & $\begin{array}{l}\text { Not applicable } \\
\text { (\%) }\end{array}$ & $\begin{array}{l}\text { Total } \\
\text { (\%) }\end{array}$ \\
\hline $20-25$ & $6(2.18)$ & $2(2.4)$ & $0(00)$ & $0(00)$ & $8(2.1)$ & $0(00)$ & $3(1.3)$ & $5(3.7)$ & $8(2.1)$ \\
\hline $26-30$ & $12(04.37)$ & $13(15.5)$ & $0(00)$ & $0(00)$ & $25(06.7)$ & $3(16.7)$ & $10(05.0)$ & $12(08.8)$ & $25(07.0)$ \\
\hline $31-35$ & $29(10.5)$ & $19(22.6)$ & $\mid z(|| .0)$ & $\mathrm{I}(33.3)$ & $50(13.5)$ & $\mathrm{I}(05.5)$ & $26(12.0)$ & $23(17.0)$ & $50(13.5)$ \\
\hline $36-40$ & $34(12.4)$ & $15(18.0)$ & $4(44.5)$ & $2(66.7)$ & $55(15.0)$ & $6(33.4)$ & $33(15.2)$ & $16(11.8)$ & $55(15.0)$ \\
\hline $4 \mid-45$ & $42(15.3)$ & $\mathrm{II}(13.0)$ & $I(I I . I)$ & $0(00)$ & $54(14.6)$ & $3(16.7)$ & $39(18.0)$ & $12(08.8)$ & $54(14.5)$ \\
\hline $46-50$ & $52(18.9)$ & $7(08.3)$ & $2(22.2)$ & $0(00)$ & $61(16.5)$ & $3(16.7)$ & $44(20.2)$ & $14(10.3)$ & $61(16.5)$ \\
\hline $51-55$ & $22(08.0)$ & $5(06.0)$ & $I(I I . I)$ & $0(00)$ & $28(07.6)$ & $\mathrm{I}(05.5)$ & $20(09.2)$ & $7(05.0)$ & $28(07.5)$ \\
\hline $56-60$ & $28(10.2)$ & $7(08.3)$ & $0(00)$ & $0(00)$ & $35(09.4)$ & $\mathrm{I}(05.5)$ & $19(09.0)$ & $15(\mid 1.0)$ & $35(09.4)$ \\
\hline $61-65$ & $24(08.7)$ & $2(02.3)$ & $0(00)$ & $0(00)$ & $26(07.0)$ & $0(00)$ & $13(06.0)$ & $13(09.6)$ & $26(07.0)$ \\
\hline $66-70$ & $25(09.1)$ & $3(03.6)$ & $0(00)$ & $0(00)$ & $28(07.6)$ & $0(00)$ & $9(04.1)$ & $19(14.0)$ & $28(07.5)$ \\
\hline Total & $274(100)$ & $84(100)$ & $9(100)$ & $3(100)$ & $370(100)$ & $18(100)$ & $217(100)$ & $135(100)$ & $370(100)$ \\
\hline
\end{tabular}

Table 3 shows that of the 370 families, 37.5 percent of the respondents were holding 1-2 acres of land, 19.4 percent of the respondents were holding 51-99 cents of land, 7.2 percent of the respondents were holding 0.50 cents of land and the same percent of respondents were holding 2-3 acres of land and 20 percent of the respondents were landless. The average size of landholding patterns varied in different types of land like 1.6 acres of revenue land, 1.5 acres of forest land and 1.3 acres of other land.

Types of crops cultivated in agricultural lands: The Soligas are currently practicing settled agriculture. They cultivate different types of crops and each crop has many varieties or species. Those who have agriculture land are involved in agricultural cultivation and the cultivated crops are used for consumption and for sale. The graphs show the types of crops cultivated by the respondent families (Figure $1)$.

According to graph 62.4 percent of the respondents consumed the cereal and 37.6 percent of the respondents did not provide an answer 52.2 percent of the respondents had used legumes for consumption and 47.8 percent of the respondents did not reply 20.8 .8 percent

of the respondents used the vegetables for consumption and 79.2 percent of the respondents did not answer. A very small percent of the respondents used other types of crops for consumption and sales. This graphs shows that the respondents used the agricultural crops for consumption and for sale.

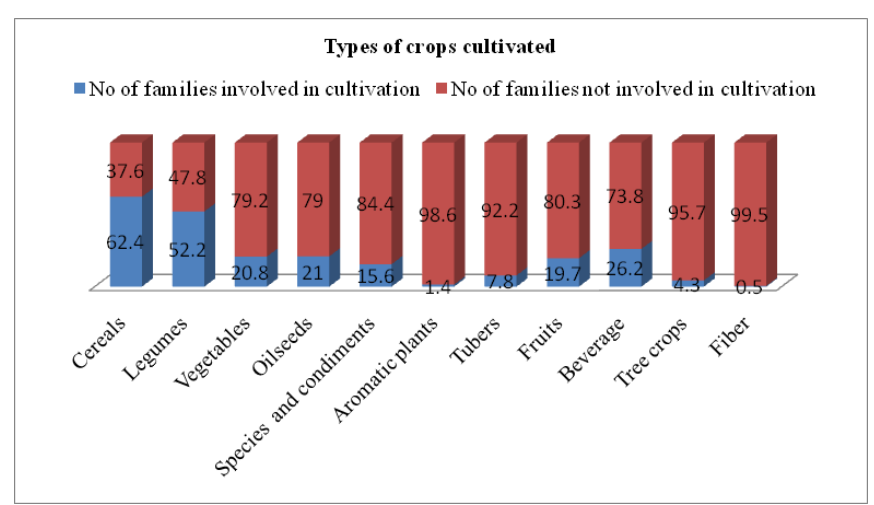

Figure I Types of crops cultivated in agricultural lands $\mathrm{N}=370$ (100\%). 
Cash and non-cash income from agriculture: The Soligas have different sources of earning like agriculture, forest, livestock and working as laborers. Earlier they used to cultivate crops for their personal consumption but nowadays they have started to cultivate some of the crops to be sold. The table explains the cash and noncash income from agriculture. Earnings from the sale of agriculture products is called cash income while agricultural products used for self- consumption is called non-cash income (Table 4).

Table 3 Types and size of landholding patterns, N= 370 (100\%)

\begin{tabular}{lllll}
\hline $\begin{array}{l}\text { Size of land in } \\
\text { acres }\end{array}$ & $\begin{array}{l}\text { No. of respondents } \\
\text { holding revenue land in } \\
\text { acres (\%) }\end{array}$ & $\begin{array}{l}\text { No. of respondents } \\
\text { holding forest land in } \\
\text { acres (\%) }\end{array}$ & $\begin{array}{l}\text { No. of respondents holding } \\
\text { other types of land in acres } \\
(\%)\end{array}$ & $\begin{array}{l}\text { No. of total respondents } \\
\text { holding land in acres } \\
(\%)\end{array}$ \\
\hline $0-50$ cents & $04(01.0)$ & $17(04.6)$ & $06(01.6)$ & $27(07.2)$ \\
5 I-99 cents & $07(02.0)$ & $59(16.0)$ & $06(01.6)$ & $72(19.4)$ \\
I-2 acre & $24(06.4)$ & $108(29.1)$ & $07(02.0)$ & $139(37.5)$ \\
$2-3$ acre & $03(00.8)$ & $21(05.7)$ & $03(00.8)$ & $27(07.2)$ \\
$3-4$ acre & $04(01.0)$ & $18(05.0)$ & $01(00.2)$ & $23(06.2)$ \\
$4-5$ acre & $01(00.2)$ & $04(01.0)$ & $01(00.2)$ & $06(02.0)$ \\
$5-6$ acre & $01(00.2)$ & $01(00.2)$ & $00(00)$ & $02(00.5)$ \\
Landless Families & $326(88.1)$ & $142(38.4)$ & $346(93.6)$ & $74(20.0)$ \\
Total & $370(100)$ & $370(100)$ & $370(100)$ & $370(100)$ \\
\hline
\end{tabular}

Of the 100 per cent, 71.3 percent of the respondents were consuming the cultivated agricultural products and 28.7 percent of the respondents did not consume the agricultural products because 20 percent of these respondents were landless and the remaining 8.7 percent of the respondents did not cultivate consumable agricultural products but may be cultivating commercial crops to sell. 70.6 percent of the respondents sold their agricultural products and 29.4 percent of respondents did not do so because 20 percent of the respondents are landless and the remaining 9.4 percent of the respondents did not sell their products as they kept it for self- consumption. ${ }^{11}$

The agriculture non- cash income per family was Rs. 2,801.50 per year and cash income per family was Rs. 5,189.27 per year making a total mean income of Rs. 7,990.77. Standard Deviation calculated on the basis of agricultural non- cash income per family of Rs. 2,795.62 per year and cash income per family was Rs. 5,047.38 comes to Rs. $7,843.00$. It was significant in the agricultural non -cash income and cash income in relation to the Mean and Standard Deviation.

Number of livestock hold by different families: Initially, the Soligas living in the forest depended on forest products for their livelihood but after some time they started to rear livestock for personal consumption which they also started to sell to outsiders. They started rearing livestock like cow, bullocks, goats, sheep and poultry. The cows and bullocks were used for agriculture purpose and the goat, sheep and poultry were used for self- consumption and for the purpose of selling. The table presents the number of respondents holding different types of livestock. The average livestock per 370 families is cow- 0.8 , bullock- 0.2 , goat- 1.3 , sheep- 0.5 and poultry- 2.7 and for the 2,905 members of the families the estimated number of livestock is cows2,324, bullocks-581, goats $-3,777$, sheep-1,453 and poultry $-7,844$. Thus, a total of 15,979 livestock comes to an average 5.5 livestock per family (Table 5).

Of the 370 respondents, 26.8 percent of the respondents have cows and 73.2 percent did not have cows; about 13.8 percent of the respondents have bullocks and 86.2 percent do not have bullocks; around 30 percent of the respondents have goats and 70 percent do not have goats, and atleast 50 percent of the respondents keep poultries and 50 percent do not keep poultries. It shows that the Soligas have the knowledge needed for livestock rearing,

Table 4 Cash and non-cash income from agriculture $\mathrm{N}=370$ (100\%)

\begin{tabular}{|c|c|c|}
\hline $\begin{array}{l}\text { Range of } \\
\text { amount in Rs. }\end{array}$ & $\begin{array}{l}\text { Agricultural non- } \\
\text { cash income (\%) }\end{array}$ & $\begin{array}{l}\text { Agricultural cash } \\
\text { income (\%) }\end{array}$ \\
\hline Upto 2,500 & $93(25.1)$ & $38(10.2)$ \\
\hline $2,50 \mathrm{I}-7,500$ & $78(21.0)$ & $68(18.4)$ \\
\hline $7501-10,000$ & $66(18.0)$ & $39(10.5)$ \\
\hline $10,00 \mid-12,500$ & $25(06.7)$ & $38(10.3)$ \\
\hline $12501-15,000$ & $02(00.5)$ & $36(10.0)$ \\
\hline$|5,00|-17,500$ & $00(00)$ & $28(07.5)$ \\
\hline$|7,50|-20,000$ & $00(00)$ & I3 (03.5) \\
\hline $20,00 \mathrm{I}-22,500$ & $00(00)$ & $01(00.2)$ \\
\hline Not applicable & $106(28.7)$ & $109(29.4)$ \\
\hline Total & $370(100)$ & $370(100)$ \\
\hline
\end{tabular}

Cash and non- cash income from livestock: Livestock contributes to the cash and non- cash income of the Soligas. Livestock used for self-consumption is a form of non-cash income and livestock sold for income is a form of cash income. It is a very important source of income, so nowadays a number of Soliga families have started to rear livestock for consumption and as well as for selling. The respondents are getting per year some cash and non- cash income per family. Indicates correlation is significant. From the above table we can conclude that there is a positive correlation between livestock non- cash income and livestock cash income. There is 56 percent of correlation between livestock non- cash income and livestock cash income. 
Table 6 shows the livestock non- cash income of 370 respondents of whom 38.1 percent of the respondents have got non-cash ranging from Rs. Up to 500 per year and 59 percent do not have non -cash income. The livestock cash income of 11 percent of the respondents range from Rs. Up to 500 per year, and of 5 percent respondents range from Rs. 5,000 and above per year. 3.8 percent of the respondents range from Rs. 3001-3,500 per year and 66.2 percent of the respondents do not have cash income. A total of 33.8 percent of respondents have got livestock cash income.

Table 5 Number of livestock hold by different families N=370 (100\%)

\begin{tabular}{|c|c|c|c|c|c|}
\hline \multirow{2}{*}{$\begin{array}{l}\text { No. of } \\
\text { livestock }\end{array}$} & Cows & Bullocks & Goats & Sheep & Poultry \\
\hline & $\begin{array}{l}\text { No. of } \\
\text { respondents (\%) }\end{array}$ & $\begin{array}{l}\text { No. of respondents } \\
\text { (\%) }\end{array}$ & $\begin{array}{l}\text { No. of respondents } \\
\text { (\%) }\end{array}$ & $\begin{array}{l}\text { No. of respondents } \\
\text { (\%) }\end{array}$ & $\begin{array}{l}\text { No. of respondents } \\
\text { (\%) }\end{array}$ \\
\hline 2-Jan & $52(14.0)$ & $43(11.6)$ & $31(08.3)$ & $18(04.8)$ & $22(06.0)$ \\
\hline 4-Mar & $25(07.0)$ & $07(02.0)$ & $34(09.2)$ & $16(04.3)$ & 51 (13.8) \\
\hline 6-May & $14(03.8)$ & $0 \mathrm{I}(00.2)$ & $22(06.0)$ & $10(02.7)$ & $60(16.2)$ \\
\hline 8-Jul & 05 (0I.3) & $00(00)$ & $03(00.8)$ & 이 (00.2) & I8 (04.8) \\
\hline I0-Sep & $02(00.5)$ & $00(00)$ & 14 (03.7) & $02(00.5)$ & $23(06.2)$ \\
\hline 10 and above & 이 (00.2) & $00(00)$ & $07(02.0)$ & $02(00.5)$ & II (03.0) \\
\hline Not applicable & 27 I (73.2) & $319(86.2)$ & $259(70.0)$ & $321(87.0)$ & $185(50.0)$ \\
\hline Total & $370(100)$ & $370(100)$ & $370(100)$ & $370(100)$ & $370(100)$ \\
\hline
\end{tabular}

The mean of livestock non- cash income per family was Rs. 139.56 per year and the cash income per family was Rs. 775.58 per year, totaling per year to Rs. 915.14 per family. The Standard Deviation of livestock non- cash income was Rs. 244.93 and cash income was Rs. $1,603.20$ thus totaling per year to Rs. $1,848.13$ per family. The mean of the livestock non- cash and cash income per year was Rs. 915.14 per family and the Std. Deviation total income per year was Rs. $1,848.13$ per family.

Types of Non timber forest products collected for sales and use: The Soliga tribal's collect the non timbers forest products(NTFPs) for livelihood for many years, NTFPs is the major sources of income to them, initial Government given the NTFPs to tender the contractors for collection, later in 1982 Government of Karnataka started the Large Scale Adivasi Multipurpose Cooperative Society ( LAMPS) and Soligas sold NTFPs through the LAMPS ,out of 28 NTFPs honey, amla, broomstick and lichen are the major NTFPs collected by the Soligas, this graphs shows that how many families involved in NTFPs collection during the research done (Figure 2). ${ }^{12}$

The graphs shows that 41 percent of respondents involved in honey collection and 59 percent of respondents did not involved in honey collection. 1.3 percent of respondents involved in Amla collection and 98.7 percent of respondents did not involve in Amla collection. 2.7 percent of respondents involved in Broomstick collection and 97.3 percent respondents did not involved in broomstick collection and 1.3 percent of the respondents involved in Lichen collection and 98.7 percent of the respondents did not involved in Lichen collection, it indicates that due the NTFPs ban in 2006 they are unable to collect NTFPS from the forest earlier they use to 50 to 60 percent of income from different NTFPs, men involved in honey, lichen and other products collection but the women majorly involved in Amla, broomstick collection and they not involved in honey and lichen collection because they are not expert in climbing tree and harvesting honey and lichen, during the data collection time ban was in place so but even though they collected. ${ }^{13}$

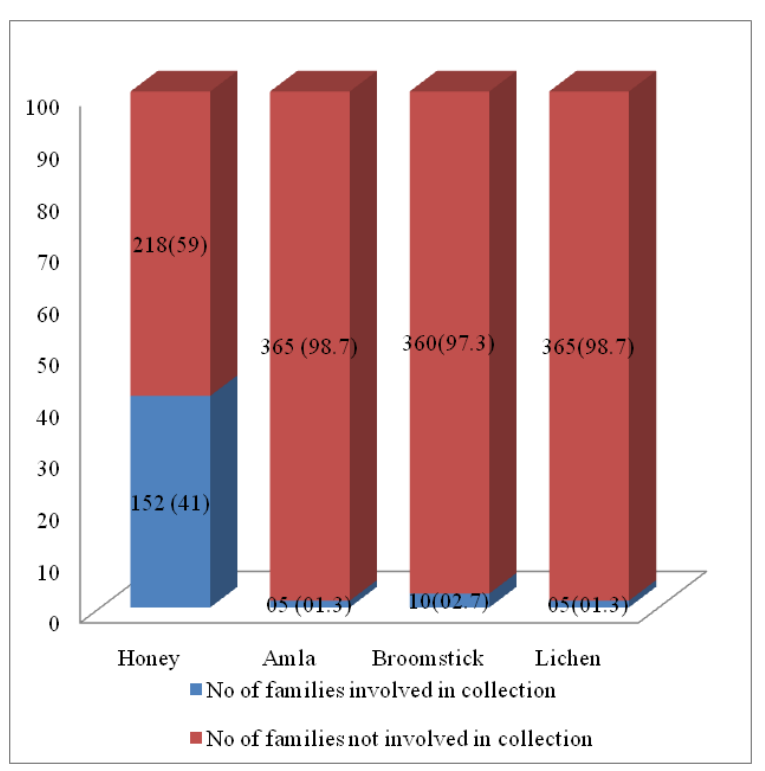

Figure 2 Types of Non timber forest products collected for sales and use $N=370(100 \%)$.

Types of forest products used for consumption: Forest is the backbone of the tribal economy. The Soligas have depended on the forest from generations. They use different types of leaves, fruits, tubers, honey, bamboo shoot, barks, roots and seeds in their everyday life as these products are available in different seasons of the year. The figure explains the different types of forest products which may or may not be used by the respondent families (Figure 3). The figure indicates that 99.7 percent of the respondents use different types of leaves and 0.3 percent of the respondents did not use the leaves. 98 percent of the respondents consumed fruits and two percent of the respondents did not. 82.2 percent of the respondents were using tubers and 17.8 percent of the respondents were not using tubers. 64 percent 
of the respondents were using honey 71.6 percent of the respondents were using bamboo shoots, and 61 percent of the respondents were using mushrooms.

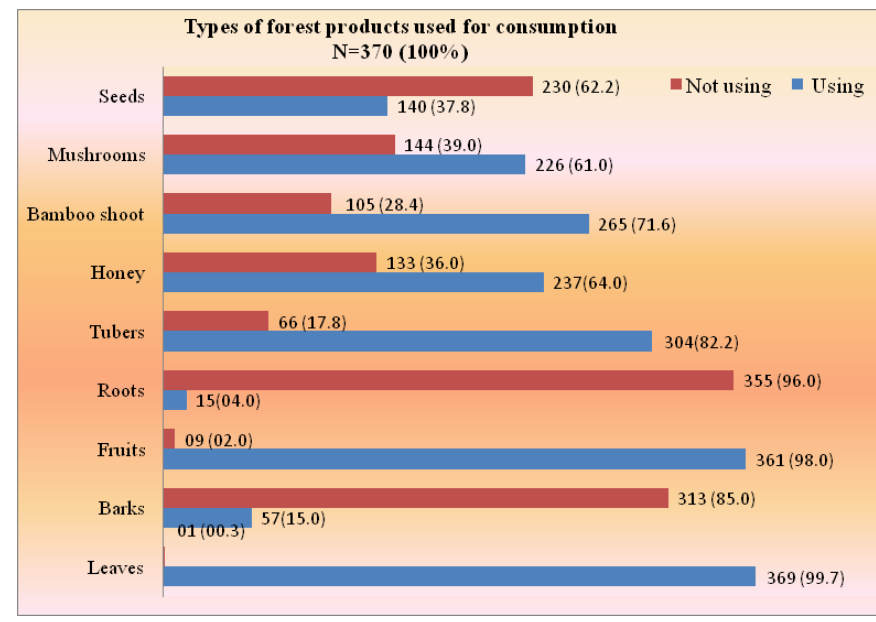

Figure 3 Types of forest products used for consumption $N=370$ (100\%).

Cash and non- cash income from the forest: The Soligas collect leaves, fruits, tubers, honey, bamboo shoots, mushrooms, seeds, barks, roots for consumption and NTFPs like honey, lichen, amla, soap nut, soapberry, bee wax, wild mango and make broomsticks, etc. to sell. The Male Soliga gathers minor forest produce from the forest and also work as laborers in the forest department. ${ }^{14}$ The NTFPs so collected are sold through LAMPS. Before 2004 NTFPs provided a major source of income to the Soligas. The NTFPs collection was strictly banned by the forest department in 2006, because of which the Soligas faced livelihood insecurity, and were forced to migrate out of the forest for employment. The table shows the cash and non- cash income from forest. In this case, cash income means the earnings from the sale of NTFPs, while non- cash income means the forest resources used for self- consumption. The table explains the cash and non- cash income from the forest and the income distributed in various ranges of Rs. up to 500 to Rs. 2,001- 2,500 (Table 7).

Table 6 Cash and non-cash income from livestock $N=370(100 \%)$

\begin{tabular}{|c|c|c|}
\hline \multirow[t]{2}{*}{$\begin{array}{l}\text { Range of } \\
\text { Amount in Rs. }\end{array}$} & \multirow{2}{*}{$\begin{array}{l}\text { Livestock non- cash } \\
\text { income } \\
\text { No. of respondents (\%) }\end{array}$} & \multirow{2}{*}{$\begin{array}{l}\text { Livestock cash income } \\
\text { No. of respondents (\%) }\end{array}$} \\
\hline & & \\
\hline Up to 500 & $14 \mid(38.1)$ & $4 \mid(I I .0)$ \\
\hline $50 \mathrm{I}-\mathrm{I}, 000$ & $10(02.7)$ & $10(02.7)$ \\
\hline $\mathrm{I}, 00 \mathrm{I}-\mathrm{I}, 500$ & $00(00)$ & $07(02.0)$ \\
\hline $\mathrm{I}, 50 \mathrm{I}-2,000$ & $00(00)$ & $06(01.6)$ \\
\hline $2,00 \mathrm{I}-2,500$ & $00(00)$ & $12(03.2)$ \\
\hline $2,50 \mathrm{I}-3,000$ & $00(00)$ & $06(01.6)$ \\
\hline $3,00 \mathrm{I}-3,500$ & $0 \mathrm{I}(00.2)$ & $14(03.8)$ \\
\hline $3,50 \mathrm{I}-4,000$ & $00(00)$ & $02(00.5)$ \\
\hline $4,00 \mathrm{I}-4,500$ & $00(00)$ & $06(01.6)$ \\
\hline $4,50 \mathrm{I}-5,000$ & $00(00)$ & $03(00.8)$ \\
\hline 5,000 and above & $00(00)$ & $18(05.0)$ \\
\hline Not applicable & $218(59)$ & $245(66.2)$ \\
\hline Total & $370(100)$ & $370(100)$ \\
\hline
\end{tabular}

From the above table we can conclude that there is a positive correlation between the cash income and non- cash forest income from the forest. There is 28.6 percent correlation between the cash income and non- cash income from the forest. Table 6, 12 presents the cash income from the forest of the 370 respondents, 11.8 percent respondents earn in the range of Rs. upto-500 per year, 11.3 percent earn in the range of Rs. 501-1,000 per year and 59.1 percent had no earnings. In the category under the non- cash income from the forest, 46 percent of the respondents earned in the range of Rs. 501-1,000 per year, 23 percent earned in the range of Rs. Up to- 500 per year, 20.8 percent of respondents earned in the range of Rs.1,001-1,500 per year. On the whole 100 percent of the respondents used the forest products for consumption, 40.9 percent sold NTFPs products, and 59.1 percent were not involved in any of the activities. The mean cash income from the sale of NTFPs per year was Rs. 417.09 per family and non- cash income per year was Rs. 895.26 per family, making it a total of Rs. 1,312.35 per year per family. As for standard deviation of income from the forest, the non- cash income was Rs. 471.70 and the cash income was Rs. 632.19 totaling per year to Rs. $1,103.89$ per family.

Types of labour work: The Soliga tribal's have the different sources of income, among that labour is major sources to them earlier days they involved in the forest based occupation, due to the forest policies impact their occupation due to that they are shifting to more for labour work, this graph shows how the Soliga families involved in labour work within the labour work they engaged different types of labour work. The graph shows that out of different types of 51.3 percent of them involved in agricultural labour, 29.7 percent of them involved in NTFPs/labour, 25.7 percent of them involved in NREGS and 8.4 percent of them involved coffee estate work and other types of labour opportunities was very less to them and very minimum number of respondents not involved in any labour work because they are continued the agriculture activities (Figure 4).

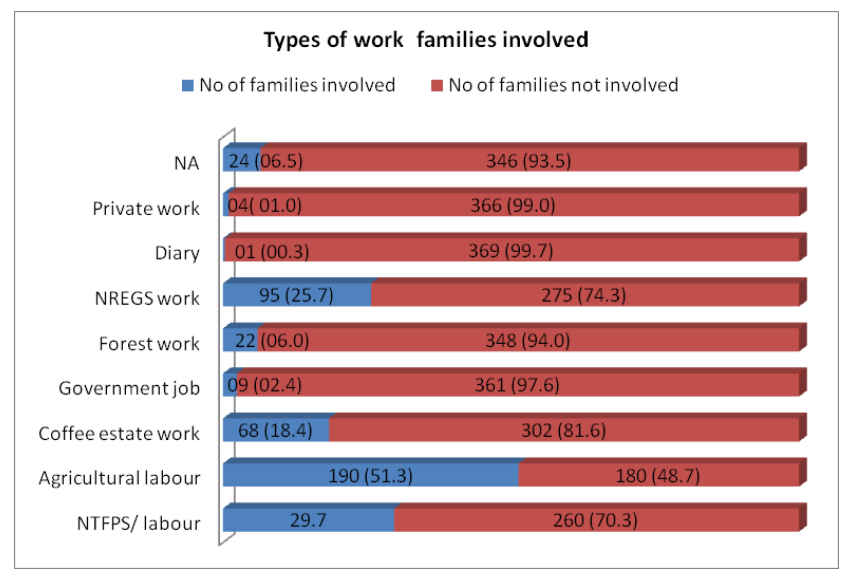

Figure 4 Types of labour work engaged by the respondents $\mathrm{N}=370(100 \%)$.

Income from labour work: The Soligas are also earning an income from labour. Working as a laborer in an agricultural field, migration labour, working in the private sector, Government job, construction work, brick making, etc. are all sources of earning an income from labour. The respondent families are involved in agricultural work, collection of NTFPs and rearing of livestock after which they are involved in labour work and 25 percent of the landless respondents were working as laborers throughout the year. So it not only lists the income of the head of the house, but also includes the income of all the eligible family members who work. Table 8 indicates the range of income earned through labour. Of the 370 respondents, 26 percent of the respondents earned an income in the range of Rs. 5,001-7,500 per 
year, 23.2 percent earned an income in the range of Rs. 2,501-5,000 per year and 18.6 percent earned an income in the range of Rs. 7,50110,000 per year.

Table 7 Cash and non cash income from the forest $\mathrm{N}=370$ (100\%)

\begin{tabular}{lll}
\hline $\begin{array}{l}\text { Range of } \\
\text { amount in Rs. }\end{array}$ & $\begin{array}{l}\text { Cash income from } \\
\text { the forest no. of } \\
\text { respondents (\%) }\end{array}$ & $\begin{array}{l}\text { Non- cash income } \\
\text { from the forest no. } \\
\text { of respondents (\%) }\end{array}$ \\
\hline Up to 500 & $44(I I .8)$ & $85(23.0)_{-}$ \\
$50 \mathrm{I}-\mathrm{I}, 000$ & $42(\mathrm{II} .3)$ & $\mathrm{I} 70(46.0)$ \\
I,00I-I,500 & $35(09.4)$ & $77(20.8)$ \\
I,50I-2,000 & 2 I (06.0) & $27(07.2)$ \\
$2,00 \mathrm{I}-2,500$ & $09(02.4)$ & $\mathrm{II}(03.0)$ \\
Not applicable & 2 I9 (59.I) & $00(00)$ \\
Total & $370(100)$ & $370(100)$ \\
\hline
\end{tabular}

Of the 370 respondents, 79.8 percent of the respondents earned an income in the range of Rs. 2,501-5,000 to 10,001-12,500 and three percent of the respondents were not engaged in labour work but were involved the agricultural and other related works. It shows that Soligas are more dependent on labour work and is a major source of income. The mean per year was Rs.7, 751.08 and the standard deviation per year was Rs. 4,244.67 per family.

Total cash and non- cash income: The Soligas earn their income from different sources which are classified into two categories as cash income and non- cash income. Cash income is earned through selling forest products and livestock, agriculture, labour work, etc. and non-cash income is the products used for self- consumption. Earlier everything would be for personal consumption but under the influence of the outside world and the growing basic needs of the family they have started to sell both, collected and cultivated products. This table explains the distribution of cash and non- cash income among the different families, ranging from Rs. upto-5,000 to Rs 25,000 and above.

From the table we can conclude that there is a positive correlation between non- cash income and cash income. There is 65.8 percent of correlation between cash income and non-cash income. The mean of cash income is Rs. 14,133.03 and of non- cash income is Rs. 3,836.33 Table 9 presents the cash income distribution. Of the 370 respondents, 30 percent of the respondents earned an income per year ranging from Rs. 10,001-15,000 per family, 25.1 percent earned an income per year ranging from Rs. 5,001-10,000 per family and 23 percent earned an income per year ranging from Rs.15, 001-20,000. Of the 370 respondents, 78.1 percent of the respondents' income per year ranged from Rs. 5,001-10,000 to Rs. $15,001-20,000$ per family.

Of the 370 respondents, 65.7 percent of the respondents earned a non-cash income per year ranging from Rs. Upto-5,000 per family, 32.7 percent earned an income per year ranging from Rs. 5,00110,000 per family, and 98.4 percent earned an income per year of less than Rs. 10,000 per family. The average non- cash income per family was Rs. $3,836.33$ per year and cash income per family was Rs. 14,133.03 per year. The total mean income per family was Rs. $17,969.30$ which shows that they earn more from cash than non- cash income. The standard deviation of non- cash income was Rs. 2,801.47 and for the cash income was Rs. 5,999.81totalling per year to Rs. $8,801.28$ per family.

Table 8 Income from labour work N=370 (I00\%)

\begin{tabular}{|c|c|}
\hline Range of amount in Rs. & No. of respondents (\%) \\
\hline upto-2,500 & $19(05.1)$ \\
\hline $2,50 \mathrm{I}-5,000$ & $86(23.2)$ \\
\hline $5,00 \mathrm{I}-7,500$ & $96(26.0)$ \\
\hline $7,50 \mathrm{I}-10,000$ & $69(18.6)$ \\
\hline $10,001-12,500$ & $44(12.0)$ \\
\hline$|2,50|-15,000$ & $26(07.0)$ \\
\hline $15,00 \mid-17,500$ & II (03.0) \\
\hline$|7,50|-20,000$ & $05(0 \mid .3)$ \\
\hline 20,000 and above & $03(00.8)$ \\
\hline Not applicable & II (03.0) \\
\hline Total & $370(100)$ \\
\hline
\end{tabular}

Total income from different sources: The cash and non- cash income earned from agriculture, livestock, forest and labour is shown in varying ranges as distributed among the 370 families. Income plays a very important role in an individual families' food, health and other needs. If individual families get less income they have to face a variety of problems. Every year they cannot earn the same amount of income because agriculture and forest depend on the rains and climate, both of which are unpredictable. The policy of the forest department banning the collection of NTFPs in 2004 effected the economy of the Soligas, likewise income from labour is also dependent on the availability of labour work in the local areas otherwise they had to migrate outside for employment and NTFPs collection is a source of uncertain income. The table shows the income distribution among the 370 families and the income per family per year.

Table 10 indicates that of the 370 respondents, 27 percent of the respondents earned in the range of Rs. 10,001-15,000 per year, 23.5 percent earned in the range of Rs. 15,001-20,000 and 19.5 percent earned in the range of Rs. 20,001-25,000 per year. Among them 70 percent of the respondents' income per year was distributed in the range of Rs. $10,001-15,000$ to Rs. $20,001-25,000$ per family. This income includes the cash and non- cash income of the individual respondents. The mean income per year was Rs. 17,969.36 per family and the standard deviation per year was Rs. 7,019.03 per family and the income per month was Rs. 1,497.44 per family. The per capita income per month per person was Rs. 354.02 and the per capita income per day per person was Rs. 29.50. Presently they are getting per capita income of Rs. 11.80 per person per day which is insufficient for an individual persons' food and other needs and so they are living below the poverty line. The 1980 benchmark survey revealed that 90.63 percent tribal's in Dharni live below the poverty line (BPL), which was then drawn at Rs. 3,600/- per annum income. ${ }^{15}$ Hence, the Government needs to provide livelihood related economic programmes and MGNREGA scheme to be implemented in tribal areas.

Sources of income: The Soligas average source of income is from the sale of forest products and livestock, agriculture and labour. This income percentage- wise per individual family comes to agriculture 
Rs. 7,990.77, livestock- Rs. 915.14, forest products - Rs. 1,312.35 and labour - Rs. 7, 751.08 totally Rs 17,969.34 per year (Figure 5). The figure explains that individual respondents have different sources of income, 43 percent earn from labour, 45 percent from agriculture, 7 percent from sale of forest resources, and 5 percent from sale of livestock. 73 percent of the tribal's out their living from agriculture. While cultivators amount to only 17 per cent, the remaining 56 percent are laborers; tribal's living inside the forests. They (671 forest settlements) are engaged in gathering non-timber forest products and forest protection work. This shows that the Soligas earn more income from labour and agriculture compared to the other two sources of income.

Table 9 Total cash and non- cash income $\mathrm{N}=370$ (100\%)

\begin{tabular}{lll}
\hline $\begin{array}{l}\text { Range of } \\
\text { amount in Rs. }\end{array}$ & $\begin{array}{l}\text { Cash income no. of } \\
\text { respondents (\%) }\end{array}$ & $\begin{array}{l}\text { Non- cash income no. } \\
\text { of respondents (\%) }\end{array}$ \\
\hline Upto-5,000 & $13(03.5)$ & $243(65.7)$ \\
$5,00 \mathrm{I}-\mathrm{I} 0,000$ & $93(25 . \mathrm{I})$ & $12 \mathrm{I}(32.7)$ \\
$\mathrm{I} 0,00 \mathrm{I}-\mathrm{I} 5,000$ & $\mathrm{I} \mid \mathrm{I}(30.0)$ & $06(0 \mathrm{I} .6)$ \\
$\mathrm{I} 5,00 \mathrm{I}-20,000$ & $85(23.0)$ & $00(00)$ \\
$20,00 \mathrm{I}-25,000$ & $52(14.0)$ & $00(00)$ \\
25,000 and above & $16(04.4)$ & $00(00)$ \\
Total & $370(100)$ & $370(100)$ \\
\hline
\end{tabular}

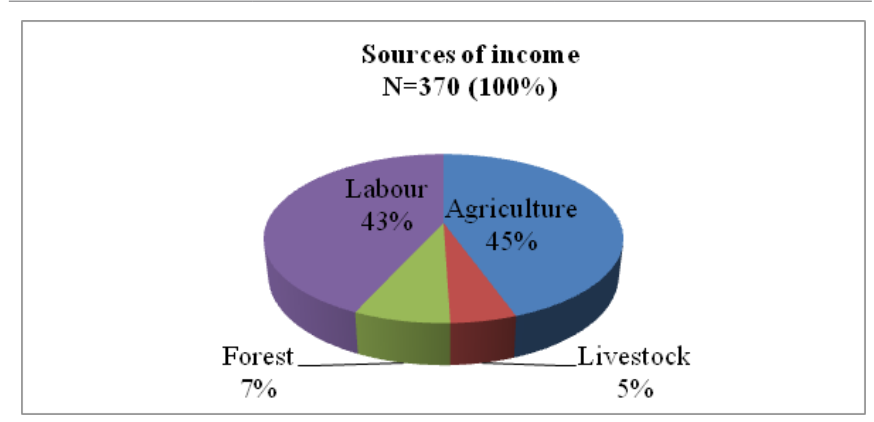

Figure 5 Sources of income $\mathrm{N}=370$ (100\%).

Types of expenditure in a year: The average expenditure by the Soligas was on food, clothes, education, and medical, travel, light, festivals, alcohol, smoking, cosmetics, etc. The per year per family expenditure was as follows: Education - Rs. 357, Medical treatment - Rs. 745, Travel-Rs. 1,128, Light- Rs. 412, Festivals - Rs. 1,411, Smoking - Rs. 1,632, Alcohol - Rs. 144, Cosmetics - Rs. 413, FoodRs. 11,137 and Clothes-Rs. 2,574, which adds up to a total of Rs. 18,542 per family per year. The same is represented in percent in the figure below. The figure confirms that 60 percent of the money was spent on food items, 14 percent was spent on clothes, nine percent was spent on smoking and the other expenditures are small in number. Around 10 percent of the money was spent on habits such as smoking and alcohol. So there is a need to make them aware of these habits (Figure 6).

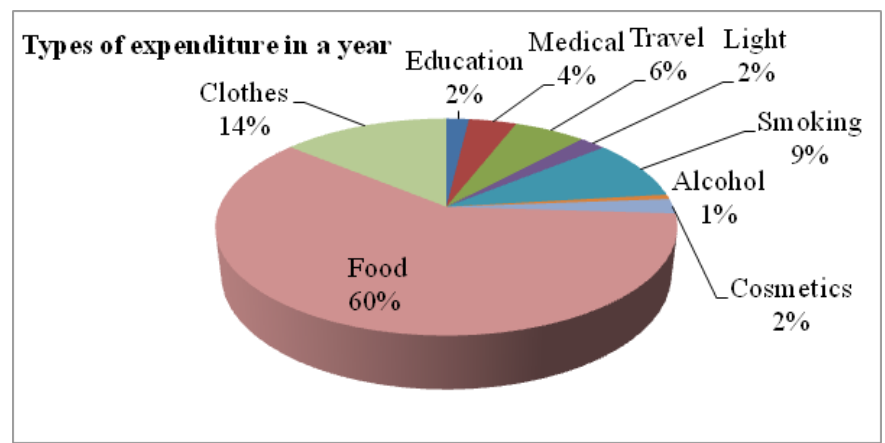

Figure 6 Types of expenditure in a year $\mathrm{N}=370$ (100\%).

Types of household assets: In the past the Soligas had not possessed any assets. They had owned their huts and some vessels. Later on they started to buy basic assets needed which over the years they started to accumulate. The household assets owned by individual respondent families are the hut, pakka house, toilet, cot, chair, table, radio, watch, television, CD player, bicycle, motorcycle and gold. The assets are classified into three categories like own, Government and NGOs. The table below explains the types of household assets owned by the respondent families.

Table 11 shows that 71.9 percent of the respondents own a radio, 44.6 percent have a watch, 20.3 percent have bicycle and television, and due to the influence of the outside the world 5.7 percent possessed gold. The Government provided 71.6 percent pakka houses, 10 percent was provided by the NGOs and 16.4 percent did not have pakka houses. The Government provided limited number of toilets, bicycles, etc. From the list of assets like the hut, pakka house, toilet, cot, chair, table, radio, watch, television, $\mathrm{CD}$ player, bicycle, motorcycle and gold owned by individual respondents, the house, toilet and bicycle had been provided by the Government, the NGOs provided the houses, while less than 20 percent of the assets like the radio, watch, etc. had been purchased by the Soligas.

Table 10 Total income from different sources $\mathrm{N}=370$ (I00\%)

\begin{tabular}{ll}
\hline Range of income in Rs. & No. of respondents (\%) \\
\hline Upto 5,000 & $05(01.4)$ \\
$5,00 \mathrm{I}-10,000$ & $38(10.2)$ \\
I0,00I-15,000 & $100(27.0)$ \\
I5,00I-20,000 & $87(23.5)$ \\
$20,00 \mathrm{I}-25,000$ & $72(19.5)$ \\
$25,00 \mathrm{I}-30,000$ & $49(13.3)$ \\
30,000 and above & $19(05.1)$ \\
Total & $370(100)$ \\
\hline
\end{tabular}

Table II Types of household assets N=370 (100\%)

\begin{tabular}{llllll}
\hline $\begin{array}{l}\text { Types of } \\
\text { Assets }\end{array}$ & Own & Government & NGOs & $\begin{array}{l}\text { Did not have } \\
\text { assets }\end{array}$ & $\begin{array}{l}\text { Total no. of } \\
\text { respondents (\%) }\end{array}$ \\
\cline { 2 - 5 } & No. of respondents (\%) & No. of respondents (\%) & No. of respondents (\%) & No. of respondents (\%) \\
\hline Hut (kucha) & $73(19.7)$ & $00(00)$ & $00(00)$ & $297(80.3)$ & $370(100)$ \\
Pakka house & $07(01.8)$ & $265(71.6)$ & $37(10)$ & $061(16.4)$ & $370(100)$
\end{tabular}




\begin{tabular}{llllll} 
Farm shed & $14(03.8)$ & $00(00)$ & $00(00)$ & $356(96.2)$ & $370(100)$ \\
Toilet & $03(00.8)$ & $01(00.2)$ & $00(00)$ & $366(99.0)$ & $370(100)$ \\
Cot & $13(03.5)$ & $00(00)$ & $00(00)$ & $357(96.5)$ & $370(100)$ \\
Chair & $11(03.0)$ & $00(00)$ & $00(00)$ & $359(97.0)$ & $370(100)$ \\
Radio & $266(71.9)$ & $00(00)$ & $00(00)$ & $104(28.1)$ & $370(100)$ \\
Table & $02(00.5)$ & $00(00)$ & $00(00)$ & $368(99.5)$ & $370(100)$ \\
Watch & $165(44.6)$ & $00(00)$ & $00(00)$ & $205(55.4)$ & $370(100)$ \\
Television & $75(20.3)$ & $00(00)$ & $00(00)$ & $295(79.7)$ & $370(100)$ \\
CD player & $39(10.5)$ & $00(00)$ & $00(00)$ & $331(89.5)$ & $370(100)$ \\
Bicycle & $57(20.3)$ & $02(00.5)$ & $00(00)$ & $311(84.0)$ & $370(100)$ \\
Motorcycle & $04(01.0)$ & $00(00)$ & $00(00)$ & $366(99.0)$ & $370(100)$ \\
Gold & $21(05.7)$ & $00(00)$ & $00(00)$ & $349(94.3)$ & $370(100)$ \\
\hline
\end{tabular}

\section{Discussion}

\section{Impact of Forest policy}

The Soligas have inhabited these forests for hundreds of years now. Till nearly 200 years ago they led an uninterrupted life of plenty, practicing shifting cultivation, hunting small game and gathering roots and greens to supplement their food. The families would gather the food separately but consume it collectively. When an individual harvested his land all the members of the settlement would visit him and take a share of his produce. ${ }^{16}$ The forest department put a stop to the practice of shifting cultivation when the Government of India brought out the Wildlife Protection Act in 1972, whereby B.R.Hills reserve forest was declared as BRT Wildlife Sanctuary in 1974. Soligas used to practice shifting cultivation till a few years ago. Land is held by individual cultivators but the forest is controlled by the government, as shifting cultivation has been banned. ${ }^{14,7}$ Most of the Soligas were shifting cultivators in 1965 and now there are no shifting cultivators'. ${ }^{17}$ The declaration of the BRTWS in 1974 forced these people in to a complete change in their lifestyle and made them more sedenta. ${ }^{18}$ Thereafter, Soligas started NTFPs collection; settled agriculture, wage labour and some among them were employed in Government sectors too.

The NTFPs collection was stopped in 2004 and was strictly enforced in 2006 under the Wildlife Protection Act, 1972. It adversely affected the livelihood of the Soligas and the government did not provide any alternative employment. The Soligas have since then adapted to these changes although NTFPs collection remained a major sources of cash income, but was banned in 2006 following an interpretation of a Supreme Court ruling banning the removal of anything from wildlife sanctuaries. ${ }^{18}$ Due to the NTFPs ban, the Soliga families started to migrate to other places for employment the ban on NTFP collection has reduced an already thin earning, by 50 to 90 per cent. Many families are migrating to find work, which has a serious impact on the social life and increases the chances of exploitation. The government has provided no alternative solution to this problem. ${ }^{19}$ The NTFP ban caused $32.5 \%$ of the Soligas to migrate to Tamil $\mathrm{Nadu}$, Kerala and also within the state looking for employment Both male and female members had migrated and in some cases the entire family had migrated as it affected the children's education, but a few families left their children in their native places as it affected the children's education and also the child-parent relationship. The Soligas are adopting the outside culture and losing their traditional values..$^{20}$ During the ban period Soligas faced the economic crisis and it also affect their lifestyle and culture. Again Government declare the BRT Wildlife Sanctuary as BRT Tiger reserve in $24^{\text {th }}$ January 2011 to conserve the Tiger and wildlife it affected the Soligas livelihood and displacement, after notification forest department identified some of the settlement for relocation it is under the process it may affect the livelihood and culture of the Soliga tribal's.

\section{Occupational changes}

The types of occupation have changed over the years, from traditional to modern. The Soligas were a foraging community. Later on they started to cultivate crops following the method of shifting cultivation along with collecting forest resources for their livelihoods. Majority of the Soligas of Mysore State are engaged in cultivation. Quite a few also follow other occupations like collection of forest products, labour in the Forest Department (in connection with felling, planting and maintenance of trees) etc. ${ }^{21}$ Land and forest are the main natural resources of the Soliga. Since the Urali Soliga are traditional cultivators, they depend on land whereas the Male Soliga gather minor forest produce from the forest and also work as laborers in the forest. ${ }^{14}$ Now they have taken to forest and agricultural labour. A few of them are landowning cultivators. ${ }^{8}$ The BRT Sanctuary has 16,000 Soligas living in 62 Podus. Their predominant livelihoods are agriculture, NTFP collection and labour in coffee estates or forest department services. ${ }^{11}$ That the overwhelming .The outside society has influenced the tribal communities, especially the Soligas who are engaged in agriculture besides other individual families who collected non-timber forest product (NTFPs) or worked as wage labour. Since the Soligas are dependent on agriculture, NTFPs collection and wage labour, the Government needs to provide alternate job opportunities or skills based work for them.

\section{Types and size of landholding}

Land plays a major role in the individual economy among the Soliga families. If an individual does not possess land he has to earn his living as a wage laborer and this is uncertain work. On the other hand if an individual holds land there is an assurance of a minimum income every year. 61.6 percent of families hold Forest land, 11.9 percent of families hold revenue land, 16.4 percent of families hold Revenue, forest and lease land and 20 percent of landless families found are landless found. The average size of landholding patterns varied in different types of land like 1.6 acres of revenue land, 1.5 acres of forest land and 1.3 acres 
of other land, the total 1.5 acres is the average size of land holding by the Soliga families in BRT Wildlife Sanctuary. The Government needs to provide land to the landless families which can help individual family economy. The current landholding is not sufficient to feed a whole family for which a minimum of five acres of land is required. This will help to add to the family economy

\section{Sources of income}

The forest plays the very important role in economy of the Soliga tribal's, traditional they collect NTFPs, other consumption products, agricultural and labour. The traditional economy of the Soliga is mostly based on shifting cultivation and collection of minor forest produce. There also other small economic activities, like hunting, trapping, fishing, and honey collecting. ${ }^{6}$ NTFPs are important to the economy of the tribal's living in the forest and they get nearly 50-60 percent of income from NTFPs. ${ }^{22}$ The three sites differed markedly in their dependence on NTFPs. The community at B.R.Hills derived nearly 59 percent of their total cash income from NTFPs, that in Nagara hole- 24 per cent and that of MM Hills- 16 percent. ${ }^{23}$ The Soligas of BRT Wildlife Sanctuary get income from NTFPs (forest), agriculture, labour and livestock. Since the Soligas are presently more involved in cultivation and use the cultivated crops for personal consumption and for sale. Around 75 percent of them hold land and 25 percent of them landless families among the Soligas, so the Government could provide land based development activities like agricultural and horticultural schemes to improve the income of the Soligas. They also involved in livestock rear like cows, bullocks, goats, sheep and poultry, the livestock comes to an average 5.5 livestock per family. So there is a need for the Government to provide the livestock and the necessary training to rear them. Hence the Government could help and provide the livestock as it help augment the Soliga income. The Soligas were dependent more on forest produce such as leaves, fruits, tubers, honey and bamboo shoots for their daily use and it is a very important source of livelihood for them. Due the NTFPs ban they unable to collect NTFPs, even the ban also they collected some of the NTFPs for sales and consumption. In 2009-2010 Soligas received more non- cash income as compared to cash income from the sale of few NTFPs products while most of the products were used for consumption. Earlier they used to earn more from the sale of NTFPs, but due to the ban on the collection of NTFPs in 2006, their income has reduced and they also getting the income from the labour, labour also one of the sources of income to them. The Soligas depend on labour; hence the Government could provide employment under the Mahatma Gandhi National Rural Employment Guarantee Act (MGNREGA), 2005. ${ }^{24}$

They were getting income from different sources among that agriculture, labour, NTFPs and livestock. 47 percent earn from labour, 32 percent from agriculture, 18 percent from sale of forest resources and 3 percent from sale of livestock. This shows that the Soligas earn more income from labour and agriculture compared to the other two sources of income. The mean income per year was Rs. 17,969.36 per family and the standard deviation per year was Rs. 7,019.03 per family and the income per month per person was Rs. 1,497.44 per family. The per capita income per month per person was Rs. 354.02 and the per capita income per day per person was Rs. 29.50. Presently they are getting per capita income of Rs. 11.80 per person per day which is insufficient for an individual persons' food and other needs and so they are living below the poverty line. The 1980 benchmark survey revealed that 90.63 percent tribal's in Dharni live below the poverty line (BPL), which was then drawn at Rs. 3,600/- per annum income ${ }^{15}$ Hence, the Government needs to provide livelihood related economic programmes and MGNREGA scheme to be implemented in tribal areas and NTFPs collection rights. Hence the Forest Department should allow them to collect these forest products.

\section{Conclusion}

The Soligas had been involved in two types of occupation, namely, primary and secondary. The study observed that none of them have a permanent or stable income to lead their life peacefully. The study found that 25 percent have become landless families. The current landholding is not sufficient to feed a whole family and there is a need for Government intervention to upgrade the family income. The per capita income per month per person was Rs. 354.02 and the per capita income per day per person was Rs. 29.50. Presently they are getting per capita income of Rs. 11.80 per person per day which is insufficient for an individual persons' food and other needs and so they are living below the poverty line. In order to economically empower the Soligas, a minimum size of land for each family is a necessity for agricultural and horticultural loan, and irrigation facilities for their agricultural land. Education and employment also needs to be provided by the Government to improve the economy of the Soligas.

The ban on shifting cultivation and NTFPs collection under the Wildlife Protection Act 1972, it impacted the livelihood and culture of the Soligas and 32.5 percent of the families migrated for employment and Government did not provide any alternative employment to them and again Government declare BRT wildlife sanctuary as a tiger reserve, so that Soligas are facing the displacement. Recently the Soligas of BRT Tiger Reserve of 30 Podus got the NTFPs collection and sale rights under the Scheduled Tribal's and Other Traditional Forest Dwellers (Recognition of Forest Right) Act 2006, in 2011 and land rights in 2010, so the Government needs to provide NTFPs collection, land and other rights to them under FRA 2006, it will help livelihood of the Soliga tribal's. Historically Soligas involved in protecting the forest and wildlife, so the Government need to involve them in biodiversity conservation without displacement tribal communities. ${ }^{25-28}$

\section{Acknowledgements}

We would like to thank Dr. Siddappa Setty. R, Fellow, Dr. Nitin D. Rai, Fellow, Ashoka Trust for Research in Ecology and the Environment (ATREE), Bangalore for supports and cooperation, Dr. Mohan A.K, Associate Professor, Department of Studies in Social Work, Central University Kasaragudu, Kerala, for supports and encouragement, Dr. H. Sudarshan, Vivekananda Girijana Kalayani Kendra, B.R.Hills for supports and the Soliga tribals of BRT Wildlife Sanctuary for providing the information for this paper.

\section{Conflict of interest}

Authors declare there is no conflict of interest in publishing the article.

\section{References}

1. Bhowmick, Chandra A. Seeing the forest from tribal life. In: Georg P \& Depak KB, editors. Contemporary Society: Tribal Studies Structure and process (Vol 1), Concept Publishing Company, India; 1997. p. 277-287.

2. Tripathy SN. Tribals in India: Problems and Policies (An Historical Analysis). Tribal labour in India, Mohit Publication, India; 1997. p. 41-45.

3. Prabhu P. Tribal Movements: Resistance to Resurgence. The Indian Journal of Social Work. 1998;59(1):230-249. 
4. Chaudhuri, Buddhadeb. Forest and Tribals. In: Georg P \& Depak KB, editors. Contemporary Society: Tribal Studies Structure and process (Vol.1), Concept Publishing Company, India; 1997. p. 231-246.

5. Nanjunda DC. Excluded, Isolation and Forgotten: Scheduled Tribe Experience of Karnataka, India. Asia Pacific Review of Rural and Tribal Issues. 2007;1(1):50-79.

6. Morab SG. The Soliga of Biligiri Rangana Hills. Anthropological Survey of India, India; 1977. p. 121.

7. Siddappa SR, Kamal B, Ticktin T, et al. Synthesis: Evaluation of a participatory Resources Monitoring system for Non-timber Forest Products: the Case of Amla (Phyllanthus spp.)Fruit Harvest by Soligas in South India. Ecology and Society. 2008;13(2):1-19.

8. Singh KS. Soliga/Soligaru. The Scheduled Tribes (Volume 3), Oxford India paperback, India; 2003.

9. Malini S. Is Integration into the mainstream society inevitable. In: Tamminen T, editor. A Field Report Adivasis at the Crossroads in India. Swallows of Finland, Finland; 2010. p. 69-80.

10. Madegowda C. Tribal Participation in Collection of Non-Timber Forest Products in Biligiri Rangaswamy Temple Wildlife Sanctuary: A Study conducted in Chamarajanagar District of Karnataka State. Sikkim Manipal University of Health, Medical and Technological Science, India; 2002. p. 31-36.

11. Saketh SS. Commercialization of Forest and its Impact on the Soliga Tribes on Biligiri Rangana Hills. Man and Environment. 1989. p. 201-213.

12. Ranjit TP, Kumar S. Development and Migration of Adivasis. Social Action. 2012;62:183-192.

13. Umashaanker R, Ganeshaiah KN, Krishnan S, et al. Livelihood gain and ecological cost of non-timber forest product dependence: assessing the role of dependence, ecological knowledge and market structure in three contrasting human and ecological settings in South India. Environmental Conservation. 2004;31(3):242-253.

14. Morab SG. Soliga/Soligaru. In: Singh KS, People of India, A relisted East-West Press Pvt. Ltd, India; 2003. p. 1381-1389.

15. Gautam PR, Singh RS. Displacement and Malnutrition among Tribals in Melghat Tiger Reserve. In: Behura NK, editor. The Challenges of Tribal Development. Sarup Book Publishers, India; 2011. p. 273-284.

16. Ravi K, Meena CK, Ashoka NS. Forestall Evictions from B.R Hills, A study on the impact of the proposed implementation of the Karnataka Government Wildlife Protection Act (1972) on the Soliga tribals of B.R.Hills in Mysore district. Karnataka Civil Liberties Committee, India; 1984.
17. Bhat HK. Socio-economic changes in a Tribal settlement (1965-1990) A Case Study of Soliga of Karnataka. In: Georg P, K Depak KB, editors. Contemporary Society: Tribal Studies, Development Issues Transition and Change. Vol 2, Concept Publishing Company, India; 1997. p. $116-121$.

18. Sushmita M, Nitin DR, Madegowda. Culture, Conservation and Comanagement: Strengthening Soligas Stake in Biodiversity Conservation in Bilgiri Rangaswamy Temple Wildlife Sanctuary, India. In: Verschuuren B, Robert W, et al. (Eds.), Sacred Natural sites Conserving Nature and Culture, Earthscan and IUCN, England; 2010. p. 263-271.

19. Ashish K. Living in Wilderness, Wildlife and People. Tehelka Magazine. 2008;5(39):10

20. Madegowda C, Usha CR. The Ban of Non-Timber Forest Products collection effect on Soligas migration in Biligiri Rangaswamy Temple Wildlife Sanctuary, India. Journal of Anthropology. 2013;9(1):105-114.

21. Koppad KB, Kurup AM, Burman BKR. Census of India 1961, Monograph series, Monographic study No.6, Soligaru (Scheduled Tribes of Mysore State). Ministry of Home Affairs, Office of the Registrar General, India; 1961.

22. Hegde R, Suryaprakash S, Achoth L, et al. Extraction of Non-Timber Forest Products in the Forests of Biligiri Rangana Hills, India. 1. Contribution to Rural income. Economic Botany 1996;50(3):243-251.

23. Ashish K, Nitin R, Madegowda. Green approach, Conservation. Frontline 2012;29(1):99-102.

24. Hemalatha PC. Development of Tribal Women Thrift Society and Grain Bank- A Case Study in Andhra Pradesh. In: Tripathy SN, editor, Tribal labour in India. Mohit Publication, India; 1997. p. 103-116.

25. Divya G. Losing homes. Livelihood issues. Frontline. 2010;27(26):18-31.

26. Nitin S. Stop trade. Down To Earth. 2004;13(9):38-39.

27. Vani, Somasundaram HN. A step towards Literacy (Story of literacy Jatha). In: Somasundaram HN, Kibe RV, editors. Soliga-the Tribe and its Stride. Vivekananda Girijana Kalayana Kendra, India; 1990. p. 99-108.

28. Anita VK. Adivasi-dispossessed by development and globalization. In: Tamminen T, editor. A Field Report Adivasis at the Crossroads in India, Swallows of Finland, Finland; 2010. p. 25-39. 